\title{
Pola Penyakit Infeksi Menular Seksual di Poliklinik Kulit Dan Kelamin RSP Bintang Amin Periode 2 Januari 2016 - 31 Desember 2020
}

\author{
Arif Effendi ${ }^{1}$, Eka Silvia ${ }^{2}$, Syafei Hamzah ${ }^{3}$, Muhammad Alkabir Ridhwan ${ }^{4}$ \\ ${ }^{1)}$ Departemen Kulit dan Kelamin Fakultas Kedokteran Universitas Malahayati,arif.effendi62@yahoo.com \\ ${ }^{2}$ Dosen Fakultas Kedokteran Universitas Malahayati, bundaekas@gmail.com \\ ${ }^{3)}$ Departemen Kulit dan Kelamin Fakultas Kedokteran Universitas Malahayati, syafeihamzah@gmail.com \\ 4) Fakultas Kedokteran Universitas Malahayati,Muhammadalka1510@gmail.com
}

\begin{abstract}
ABSTRAK
Infeksi Menular Seksual (IMS) adalah infeksi yang penyebarannya terutama melalui hubungan seksual. Lebih dari 30 jenis mikroorganisme yang diketahui dapat ditularkan melalui hubungan seksual. Infeksi yang paling umum termasuk gonore, klamidia, sifilis, trikomoniasis, hepatitis B, herpes genital, dan infeksi human papilloma-virus (HPV). Beberapa faktor yang mungkin berkontribusi terhadap kejadian IMS adalah faktor sosiodemografi dan perilaku. Variabel-variabel penyakit menular seksual adalah usia, status pernikahan, kelompok risiko, dan jenis kelamin. Tujuan penelitian ini untuk mengetahui pola penyakit infeksi menular seksual di Poliklinik Kulit dan Kelamin RSP Bintang Amin periode 2 Januari 2016 - 31 Desember 2020. Penelitian ini merupakan penelitian deskriptif kuantitatif dan desain cross sectional serta teknik pengambilan sampel yang digunakan adalah total sampling dengan kuesioner. Hasil penelitian didapatkan, jJumlah sampel 51 dari 51 populasi, pola penyakit infeksi menular seksual di Poliklinik Kulit dan Kelamin RSP Bintang Amin yaitu kondiloma akuminata sebanyak 28 orang (54.9\%), kandidiasis sebanyak 16 orang (31.4\%), Herpes simplex sebanyak 4 orang (7.8\%), sifilis sebanyak 2 orang (3.9\%) dan terendah Gonore 1 orang (2.0\%). Kesimpulan : Prevalensi jenis penyakit infeksi menular seksual yang paling sering terjadi di Poliklinik Kulit dan Kelamin RSP Bintang Amin periode 2 Januari 2016 - 31 Desember 2020 didapatkan yang terbanyak yaitu Kondiloma Akuminata sebanyak 28 pasien (54,9\%), dengan jenis kelamin terbanyak perempuan 40 pasien (78,4\%). Usia 25-49 tahun sebanyak 36 pasien (70.6\%), dan yang sudah berstatus menikah sebanyak 46 pasien $(90.2 \%)$.
\end{abstract}

Kata Kunci : Pola Penyakit, IMS

\begin{abstract}
Sexually Transmitted Infections (STIs) are infections that are spread primarily through sexual contact. More than 30 types of microorganisms are known to be transmitted through sexual contact. The most common infections include gonorrhea, chlamydia, syphilis, trichomoniasis, hepatitis B, genital herpes, and human papillomavirus (HPV) infection. Some of the factors that may contribute to the incidence of STIs are sociodemographic and behavioral factors. Purpose: To find out the pattern of sexually transmitted infections at the Skin and Venereal Polyclinic of Bintang Amin Hospital for the period of January 2, 2016 - December 31, 2020. Research Methods: Quantitative descriptive study and cross sectional design and total sampling technique using a questionnaire. Results: The number of samples was 51 from 51 populations, the pattern of sexually transmitted infections in the Polyclinic of Skin and Sex at RSP Bintang Amin, namely condyloma acuminata as many as 28 people (54.9\%), candidiasis as many as 16 people (31.4\%), Herpes simplex as many as 4 people (7.8\%), syphilis as much as 2 people (3.9\%) and the lowest was Gonorrhea 1 person (2.0\%). Conclusion: The prevalence of sexually transmitted infections that most often occurred in the Skin and Gender Polyclinic of Bintang Amin Hospital for the period January 2, 2016 - December 31, 2020, was obtained the most, namely condyloma acuminata as many as 28 patients (54.9\%), with the most female sex being 40 patients ( $78.4 \%)$. Age $25-49$ years were 36 patients (70.6\%), and those who were married were 46 patients $(90.2 \%)$.
\end{abstract}

Keywords: Patterns of Disease, STIS

*Korespondensi Author : Muhammad Alkabir Ridhwan, Program Studi Kedokteran Fakultas Kedokteran Universitas Malahayati, Email dan nomor telepon : Muhammadalka1510@gmail.com $/ 089506980372$

\section{PENDAHULUAN}

Infeksi Menular Seksual (IMS) adalah infeksi yang penyebarannya terutama melalui hubungan seksual. Lebih dari 30 jenis mikroorganisme diketahui dapat ditularkan melalui hubungan seksual. Infeksi yang paling 
umum termasuk gonore, klamidia, sifilis, trikomoniasis, herpes genital, dan infeksi human papilloma-virus (HPV). ${ }^{1}$ Infeksi menular seksual dapat diklasifikasikan menurut agen penyebabnya, yaitu dari golongan bakteri, yakni Neisseria gonorrhoeae, Treponema pallidum, Chlamydia trachomatis, Haemophilus ducreyi, Calymmatobacterium granulomatis, Ureaplasma urealyticum, Mycoplasma hominis, Gardnerella vaginalis, Salmonella sp, Shigella $s p$, Campylobacter sp, Streptococcus grup B, Mobiluncus sp.Dari golongan protozoa, yakni Trichomonas vaginalis, Entamoeba histolytica, Giardia lamblia, dan protozoa enterik lainnya. Dari golongan virus, yakni Human Immunodeficiency Virus (tipe 1 dan 2), Herpes Simplex Virus (tipe 1 dan 2), Human Papiloma Virus (banyak tipe), Cytomegalovirus, EpsteinBarr Virus, Molluscum contagiosum virus. Dari golongan ekoparasit, yakni Pthirus pubis, Sarcoptes scabei. Dari golongan jamur Candida albican. $^{2}$

Penyakit ini memiliki beberapa ciri, yaitu tidak semua melalui hubungan seksual, infeksi dapat terjadi pada orang yang belum pernah berhubungan seks atau seseorang tersebut tidak pernah melakukan hubungan seks namun tidak semua penyakit ini ditularkan melalui kontak langsung dan alat-alat yang tercemar seperti: hancuk, thermometer, jarum suntik, atau melalui darah, cairan vagina, sperma dan saliva. sertasebagian penderita merupakan korban akibat keadaan yang diluar kemampuannya. Cara penularan lain penyakit ini bisa dari ibu hamil kepada janin yang dikandungnya atau pada saat inpartu (proses kelahiran). Korban yang dimaksud berarti mereka berusaha semaksimal mungkin untuk tidak dapat penyakit tersebut, tetapi ternyata tetap tertular. ${ }^{3}$ Beberapa faktor yang mungkin berkontribusi terhadap kejadian IMS adalah faktor sosio demografi dan perilaku. Variabel-variabel penyakit menular seksual adalah usia, status pernikahan, kelompok risiko, dan jenis kelamin. ${ }^{4}$ Infeksi menular seksual berdampak besar pada reproduksi di seluruh dunia dan kesehatan seksual. ${ }^{1}$ CDC mengemukakan bahwa penderita penyakit menular seksual sekitar lebih dari 1 juta orang di seluruh dunia yang dapat disembuhkan setiap hari. Paling rentan terjadi pada wanita dan pria yang berusia 15 hingga 49 tahun dan penyakit menular salah satu yang paling umum dilaporkan di seluruh dunia. Dan mencapai 20 juta kasus baru infeksi menular seksual di Amerika Serikat pada 2016 dan 357 juta kasus secara global. ${ }^{5}$

Data dari skrining rutin dalam pengaturan perawatan antenatal di sub-Sahara Afrika telah menunjukkan prevalensi IMS umum, termasuk klamidia, gonore dan sifilis, setinggi $15 \%$. Hampir setengah dari semua wanita di bawah usia 30 tahun terinfeksi dengan Herpes Simplex Virus tipe 2 (HSV-2) di sub-Sahara Afrika hingga 30\% wanita hamil memiliki HIV di Afrika bagian selatan. Remaja hamil dibelahan dunia lain juga ditemukan memiliki prevalensi IMS yang tinggi, di Portugal satu penelitian menemukan $11 \%$ remaja hamil terinfeksi trikomoniasis dan 5\% dengan gonore. ${ }^{6} \mathrm{Di}$ negara-negara berkembang seperti Afrika, Asia, Asia Tenggara, termasuk Indonesia infeksi menular seksual banyak terjadi serta semakin meningkat setiap tahunnya. Hal ini juga sejalan dengan peningkatan prevalensi HIV / AIDS di negara- negara tersebut. Di Indonesia, uretritis gonore adalah infeksi menular seksual pertama, terhitung $7,4 \%-50 \%$ dari semua infeksi menular seksual. $^{7}$

Menurut Profil Dinas Kesehatan Provinsi Lampung, kasus IMS di tahun 2019 jumlah kasus HIV mengalami kenaikan sebanyak 568 kasus, dengan presentase kasus HIV laki-laki lebih besar dibandingkan perempuan. Profil Dinas Kesehatan Kota Bandar Lampung tahun 2015 menyebutkan, kasus IMS berjumlah sebanyak 2.066 kasus, terdiri dari servisitis / proctitis yang berjumlah sebanyak 1.681 kasus, uretritis nongonore 176 kasus, ulkus genital 49 kasus, sifilis 38 kasus, herpes genital 38 kasus, uretritis gonore 37 kasus, dan trikomoniasis 17 kasus. Kasus HIV laki-laki berjumlah 143 kasus dan perempuan berjumlah 140 kasus sedangkan pada kasus IMS lainnya laki-laki berjumlah 147 kasus serta perempuan berjumlah 2.303 kasus. ${ }^{3}$ Berdasarkan latar belakang permasalahan diatas, maka peneliti tertarik melakukan penelitian 
mengenai " pola penyakit infeksi menular seksual di Poliklinik Kulit dan Kelamin RSP Bintang Amin periode 2 Januari 2016 - 31 Desember $2020 "$.

\section{METODOLOGI}

Jenis penelitian yang digunakan adalah penelitian deskriptif dengan retrospektif. Penelitian ini menggunakan populasi data rekam medis pasien IMS yang datang di Poliklinik Kulit dan Kelamin RSP Bintang Amin pada tahun 2016 - 2020 sebanyak 51 pasien. Metode pengambilan sampel dengan cara total sampling yaitu sampel digunakan adalah seluruh data pasien yang di diagnosis IMS di Poliklinik Kulit dan Kelamin RSP Bintang Amin 2016-2020.

\section{HASIL DAN PEMBAHASAN}

Penelitian ini dilakukan untuk mengetahui pola penyakit infeksi menular seksual di Poliklinik Kulit dan Kelamin RSP Bintang Amin periode 2 Januari 2016 - 31 Desember 2020.

Tabel 1 Distribusi Frekuensi Jenis IMS Di Poliklinik Kulit Dan Kelamin Bintang Amin Tahun 2016-2020.

\begin{tabular}{lcc}
\hline Jenis IMS & $\mathrm{N}$ & $\mathrm{P}$ \\
\hline Sifilis & 2 & $3.9 \%$ \\
Gonore & 1 & $2.0 \%$ \\
Kondiloma akuminata & 28 & $54.9 \%$ \\
Herpes simplex & 4 & $7.8 \%$ \\
Kandidiasis & 16 & $31.4 \%$ \\
\hline Jumlah & 51 & 100 \\
\hline
\end{tabular}

Berdasarkan tabel 1 didapatkan hasil penelitian pada penderita dengan jenis IMS terbanyak adalah kondiloma akuminata sebanyak 28 pasien $(54.9 \%)$ dan terendah Gonore 1 pasien $(2.0 \%)$. Sesuai dengan hasil penelitian yang dilakukan oleh Siahaan, Anggraeni, di RSUP H. Adam Malik Medan menyatakan bahwa Kondiloma akuminata menempati urutan pertama yang paling sering diderita yaitu sebanyak 102 pasien $(35.7 \%){ }^{8}$ IMS yang banyak didapati pada urutan kedua adalah Kandidiasis sebanyak 16 pasien (31.4\%).
Hasil ini tidak sesuai dengan penelitian yang dilakukan oleh Wirakusuma di RS Umum Pusat Sanglah yang menyatakan Kandidiasis sebanyak 53 pasien $(24,9 \%)$ berada pada urutan keempat. ${ }^{9}$

Sementara diurutan ketiga adalah herpes simplex sebanyak 4 orang (7.8\%). Hasil penelitian ini berbeda dengan penelitian yang dilakukan oleh Anggraeni di RSUP H.Adam Malik medan dimana herpes simplex menempati urutan ke lima sebanyak 23 pasien $(8 \%){ }^{8}$ Diurutan keempat adalah Sifilis sebanyak 2 pasien $(3,9 \%)$. Hasil ini tidak sesuai dengan hasil penelitian yang dilakukan oleh Wirakusuma di RS Umum Pusat Sanglah dimana Sifilis menempati urutan ke lima dengan sebanyak 47 pasien $(21,5 \%){ }^{9}$

Menurut, Simanjuntak di Klinik IMS Deli Serdang mengatakan bahwa infeksi menular seksual tidak menunjukan adanya gejala yang salah satunya sifilis. ${ }^{10}$ Sehingga kebanyakan orang yang terinfeksi sifilis cenderung tidak menyadari infeksi yang dapat menularkan kekontak seksual mereka dan diurutan terakhir adalah Gonore sebanyak 1 pasien (2.0\%). Hasil ini berbeda dengan hasil penelitian yang dilakukan oleh Wirakusuma di RS Umum Pusat Sanglah dimana gonore menempati urutan ke tiga dengan sebanyak 42 pasien $(18,1 \%){ }^{9}$ Menurut, Simanjuntak di Klinik IMS Deli Serdang mengatakan bahwa banyak penderita gonore yang mencari pertolongan pada praktik dokter pribadi, klinik swasta, rumah sakit lain atau puskesmas Dan juga karena tersedianya atau masih terdapat obat yang dijual bebas di apotik. ${ }^{10}$

Tabel 2 Distribusi Frekuensi Jenis Kelamin Di Poliklinik Kulit Dan Kelamin Bintang Amin Tahun 2016-2020.

\begin{tabular}{llc}
\hline Jenis Kelamin & $\mathrm{N}$ & $\mathrm{P}$ \\
\hline Laki-laki & 11 & $21.6 \%$ \\
Perempuan & 40 & $78.4 \%$ \\
\hline Jumlah & 51 & $100 \%$ \\
\hline
\end{tabular}

Berdasarkan tabel 2 didapatkan bahwa pasien yang mengalami penyakit IMS terbanyak adalah berjenis kelamin perempuan, yaitu 40 pasien $(78,4 \%)$, sedangkan yang paling sedikit 
adalah berjenis kelamin laki-laki, yaitu 11 pasien (21,6\%). Tingginya kasus infeksi menular seksual pada wanita dari pada laki laki diduga karena wanita sulit menjaga kehigienissan area organ genital saat berhububungan seksual selain itu juga wanita memiliki area vulva yang terdiri dari labia dan klitoris yang terbuka lebar yang dapat membuat infeksi masuk dengan mudah. Wanita juga mudah sekali mengalami infeksi bila sampai ada masalah pada kelembaban, $\mathrm{pH}$, ataupun luka pada vaginanya dan juga wanita memiliki risiko tinggi mengalami infeksi berulang-ulang kali setiap bulannya. Hal ini sesuai dengan penelitian yang dilakukan oleh Panonsih, di Layanan Primer tingkat 1 di Kota Bandar Lampung dimana pasien perempuan sebanyak 711 pasien $(177,2 \%)$ lebih banyak dari laki-laki sebanyak 93 pasien $(22,8 \%) .^{3}$

Serta berbanding terbalik dengan hasil penelitian yang dilakukan oleh (Anggraeni, 2016) di RSUP H.Adam Malik medan dimana pasien laki-laki lebih banyak yaitu 156 orang (54.5\%) menderita IMS dibandingkan perempuan yaitu 130 pasien (45.5\%). Menurut, Wirakusuma di RS Umum Pusat Sanglah mengatakan hal ini disebabkan karena laki-laki lebih sering tidak ingin menggunakan kondom pada saat berhubungan seksual daripada perempuan. ${ }^{9}$ Laki-laki juga lebihbanyak beraktivitas di dalam kehidupan sehari-hari, sehingga tidak jarang laki-laki yang sudah terkena IMS berhubungan seksual pada saat bepergian ke luar kota yang akan menyebabkan peningkatan prevalensi IMS.

Tabel 3 Distribusi Frekuensi Usia Di Poliklinik Kulit Dan Kelamin Bintang Amin Tahun 2016-2020.

\begin{tabular}{lcc}
\hline Usia & $\mathrm{N}$ & $\mathrm{P}$ \\
\hline $15-19$ & 2 & $3.9 \%$ \\
$20-24$ & 4 & $7.8 \%$ \\
$25-49$ & 36 & $70.6 \%$ \\
$>50$ & 9 & $17.6 \%$ \\
\hline Jumlah & 51 & $100 \%$ \\
\hline
\end{tabular}

Berdasarkan tabel 3 didapatkan hasil penelitian dengan perbedaan usia yang paling sering menderita IMS yaitu usia 25-49 tahun sebanyak 36 pasien $(70.6 \%)$ dan usia terendah 15-19 tahun sebanyak 2 pasien (3,9\%). Usia penderita IMS dalam penelitian ini sebagian besar berada pada masa produktif, dimana aktivitas seksualnya sedang meningkat. Aktivitas seksual yang tinggi dan tanpa terkendali merupakan pintu masuk terjangkitnya IMS pada orang tersebut selain itu juga minimnya koordinasi antara pemerintah dan badan kesehatan di dalam melakukan penyuluhan mengenai IMS kepada masyarakat menjadi salah satu faktor yang menyebabkan orang tersebut terkena IMS. Sesuai dengan penelitian yang dilakukan oleh Panonsih, di Layanan Primer tingkat 1 di Kota Bandar Lampung dimana jenis usia yang terbanyak yaitu pada usia 25-49 tahun sebanyak 491 pasien $(121,7 \%){ }^{3}$ untuk urutan terendah pada usia $15-$ 19 tahun sebanyak 23 pasien $(5,7 \%)$. Hasil penelitian ini serupa dengan yang diteliti oleh Puspawati di Klinik Anggrek Ubud II menyatakan bahwa penderita yang mengalami IMS paling banyak berasal dari kelompok usia 25-49 tahun yaitu sebanyak 166 kasus $(60,8 \%){ }^{1}$ Sedangkan hasil penelitian ini tidak sesuai dengan penelitian yang dilakukan oleh Tuntun di RSUD dr.H. Abdul Moeloek menyatakan bahwa penderita IMS terbanyak dijumpai pada kelompok usia 14-25 tahun yaitu sebanyak 93 pasien (50\%). ${ }^{11}$ Menurut penelitian Anggraeni di RSUP H. Adam Malik Medan keseluruhan hasil ini menunjukkan bahwa pasien IMS paling sering berada pada usia seksual aktif sehingga rentan untuk terinfeksi IMS karena biasanya memiliki pasangan seksual yang banyak serta lebih sering berganti-ganti pasangan dibandingan dengan kelompok usia lainnya. ${ }^{8}$ Menurut, Puspawati di Klinik Anggrek Ubud II Perbedaan usia pada kelompok usia 25-49 tahun dan kelompok usia lainnya karena usia 25-49 tahun merupakan kelompok seksual aktif dan mobilitas pada kelompok umur tersebut juga tinggi sehingga resiko umtuk terkena IMS juga lebih tinggi. ${ }^{12}$ 
Tabel 4 Distribusi Frekuensi Status Pernikahan Di Poliklinik Kulit dan Kelamin Bintang Amin Tahun 2016-2020.

\begin{tabular}{lcc}
\hline Status Pernikahan & $\mathrm{N}$ & $\mathrm{P}$ \\
\hline Belum menikah & 5 & $9.8 \%$ \\
Menikah & 46 & $90.2 \%$ \\
\hline Jumlah & 51 & $100 \%$ \\
\hline
\end{tabular}

Berdasarkan tabel 4 didapatkan hasil penelitian pada pasien IMS berdasarkan status pernikahan menunjukkan bahwa pasien IMS yang sudah menikah lebih banyak yaitu ada sebanyak 46 pasien (90.2\%) dibandingkan dengan yang belum menikah sebanyak 5 pasien (9.8\%). Hasil penelitian diatas menunjukkan sebagian besar penderita IMS adalah yang sudah menikah hal ini diduga status pernikahan seseorang tidak menjamin bahwa orang tersebut untuk tidak berganti-ganti pasangan. Beberapa hal yang dapat menyebabkan seseorang untuk berganti-ganti pasangan dikarenakan pernikahan yang kurang harmonis sehingga dapat menyebabkan permasalahan dalam rumah tangga tersebut. Hal ini sesuai dengan penelitian yang dilakukan oleh Anggraeni di RSUP H.Adam Malik medan yang menyatakan bahwa pasien IMS dengan kelompok beresiko tinggi lebih banyak yang sudah menikah sebanyak 173 pasien $(60,4 \%)$ dan belum menikah sebanyak 113 pasien $(39,5){ }^{9}$ Penelitian Maan dkk, di Faisalabad - Pakistan, juga menyatakan pasien IMS lebih banyak yang sudah menikah dibandingkan dengan yang belum menikah. ${ }^{13}$ Serupa dengan penelitian yang dilakukan oleh Masni dkk, di Kota Ternate menyatakan bahwa penderita IMS dengan kelompok beresiko tinggi lebih banyak yang sudah menikah sebanyak 46 pasien $(76.7 \%)$ dari pada yang belum menikah sebanyak 2 pasien $(3,3 \%) .{ }^{14}$ Menurut, Anggraeni di RSUP H.Adam Malik Medan insiden IMS lebih banyak pada kelompok yang sudah menikah karena kelompok ini memiliki faktor yang lebih besar untuk menularkan atau tertular IMS. ${ }^{9}$

\section{SIMPULAN DAN SARAN}

Berdasarkan hasil penelitian yang dilakukan di RSP Bintang Amin periode 2
Janurari 2016 - 31 Desember 2020, maka dapat disimpulkan bahwa prevalensi jenis penyakit infeksi menular seksual yang paling sering terjadi di Poliklinik Kulit dan Kelamin RSP Bintang Amin periode 2 Januari 2016 - 31 Desember 2020 didapatkan yang terbanyak yaitu Kondiloma Akuminata dengan jumlah 28 pasien dengan presentase $(54,9 \%)$. Diketahui distribusi berdasarkan jenis kelamin pada pasien infeksi menular seksual di Poliklinik Kulit dan Kelamin RSP Bintang Amin periode 2 Januari 2016 - 31 Desember 2020 didapatkan yang terbanyak yaitu perempuan dengan jumlah 40 pasien dengan presentase $(78,4 \%)$. Diketahui distribusi berdasarkan usia pada pasien infeksi menular seksual di Poliklinik Kulit dan Kelamin RSP Bintang Amin periode 2 Januari 2016 - 31 Desember 2020 didapatkan yang terbanyak yaitu dengan usia 25-49 tahun sebanyak 36 pasien dengan presentase (70.6\%). Diketahui distribusi berdasarkan status pernikahan pada pasien infeksi menular seksual di Poliklinik Kulit dan Kelamin RSP Bintang Amin periode 2 Januari 2016 - 31 Desember 2020 didapatkan IMS terbanyak yaitu yang berstatus sudah menikah sebanyak 46 pasien dengan presentase $(90.2 \%)$.

Saran bagi penelitian berikutnya, sebaiknya mencari lokasi tempat penelitian yang lebih luas lagi supaya bisa mendapatkan lebih banyak lagi pasien sehingga pola IMS yang akan didapatkan bisa lebih bervariasi. Hasil penelitian ini di harapkan dapat memberikan informasi yang telah ada sebelumnya serta menunjang kegiatan penelitian selanjutnya di Fakultas Kedokteran Universitas Malahayati. Serta, hasil penelitian ini diharapkan menjadi bahan informasi untuk masyarakat luas agar masyarakat mampu mengenali bahkan menghindari serta meminimalkan kasus IMS.

\section{UCAPAN TERIMA KASIH}

Terima kasih kepada Fakultas Kedokteran Universitas Malahayati Lampung yang telah mendukung pelaksanaan penelitian.

\section{REFERENSI}

1. Pandjaitan, Marini C., Nurdjannah J. Niode, and Pieter L. Suling. "Gambaran 
Pengetahuan dan Sikap terhadap Infeksi Menular Seksual pada Remaja di SMA Frater Don Bosco Manado." e-CliniC 5.2. 2017.

2. Ramjee, Gita, Nathlee S. Abbai, and Sarita Naidoo. "Women and sexually transmitted infections in Africa." Open Journal of Obstetrics and Gynecology 5.07. 2015: 385.

3. Panonsih, Resati Nando. "Profil Pasien Penyakit Menular Seksual Pada Layanan Primer Tingkat I Di Kota Bandar Lampung Tahun 2015." Jurnal Medika Malahayati 3.3 2016: 159-164.

4. Lestari, Kadek Yulita Dewi, Desak Nyoman Widyanthini, and I. Ketut Tangking Widarsa. "Kejadian Infeksi Menular Seksual Berdasarkan Karakteristik Sosial Demografi Di Puskesmas Ii Denpasar Utara Tahun 2014-2016." Archive Of Community Health 5.2. 2018 : 33-42.

5. Weston, Emily J., et al. "Adherence to CDC recommendations for the treatment of uncomplicated gonorrhea STD Surveillance Network, United States, 2016." Morbidity and Mortality Weekly Report 67.16. 2018: 473.

6. Teasdale, Chloe A., et al. "Incidence of sexually transmitted infections during pregnancy." PLoS One 13.5. 2018: e0197696.

7. 7Putranti, Ismiralda Oke, et al. "PERBEDAAN PREVALENSI PENYAKIT INFEKSI MENULAR SEKSUAL DI INSTALASI RAWAT JALAN RSUD Prof. dr. MARGONO SOEKARJO PERIODE 2010-2014." Mandala of Health: A Scientific Journal 11.1. 2018: 1-8.

8. Siahaan, Elisa Anggraeni. Pola penyakit infeksi menular seksual pada pasien poli kulit dan kelamin RSUP H.Adam Malik medan tahun 2008-2012. Universitas Sumatera Utara; 2016.

9. Wirakusuma, AANB Adhitya, I. G. K. Darmada, and Luh Made Mas Rusyati. "Spektrum Infeksi Menular Seksual di Poliklinik Kulit dan Kelamin Rumah Sakit Umum Pusat Sanglah Periode 20092011." E-Jurnal Medika Udayana; 2014.
10.Tuntun, Maria. "Faktor Resiko Penyakit Infeksi Menular Seksual (IMS)." Jurnal Kesehatan 9.3. 2018: 419-426.

11.Simanjuntak, Linda Helena. "Prevalensi Infeksi Menular Seksual pada Wanita Pekerja Seks di Klinik IMS pada Tiga Puskesmas Kabupaten Deli Serdang Tahun 2010-2013.". 2016.

12.Adiguna, Md Swastika, and Ni Made Dwi Puspawati. "Prevalensi Dan karakteristik infeksi menular seksual di klinik anggrek UPT Ubud II Pada Bulan Januari-Desember 2016." E-Jurnal Medika Udayana 7.4. 2018 : 169-175.

13.Maan, Muhammad arif, fatma Hussain, Javed Iqbal, dan Shahid Javed Akhtar. Sexually Transmitted Infections in Pakistan. Ann Saudi Med 31 (3). 2011: 263-269

14.Mappajanci, Masni, Nurdiana Lante, and Arsunan Arsin. "Faktor Risiko Kejadian Infeksi Menular Seksual di Puskesmas Kalumata Kota Ternate." Media Kesehatan Masyarakat Indonesia 12.4. 2017 : 224-231. 